\title{
Unifying the p73 knockout phenotypes: TAp73 orchestrates multiciliogenesis
}

\author{
Marco Napoli ${ }^{1,2}$ and Elsa R. Flores ${ }^{1,2,3}$ \\ ${ }^{1}$ Department of Molecular and Cellular Oncology, ${ }^{2}$ Department of Translational Molecular Pathology, ${ }^{3}$ Graduate School \\ of Biomedical Sciences, The University of Texas M.D. Anderson Cancer Center, Houston, Texas 77030, USA
}

\begin{abstract}
Multiciliogenesis is essential for the function of different epithelia, and its failure results in brain defects, respiratory diseases, and infertility. In this issue of Genes $e_{t}$ Development, Nemajerova and colleagues (pp. 13001312) reveal the $p 53$ family member and $p 73$ isoform TAp73 as a transcription factor dictating the differentiation of multiciliated cells. Their findings provide the long-awaited unifying explanation for the diverse phenotypes of the $p 73$ knockout mice.
\end{abstract}

Motile cilia are specialized organelles present on many epithelia, and defects in these structures cause respiratory diseases, otitis, infertility, and hydrocephalus (Fliegauf et al. 2007). These disorders are reminiscent of the phenotypes of $p 73^{-/-}$mice, which include hippocampal dysgenesis, severe hydrocephalus, sterility, and chronic infections in the airways (Yang et al. 2002). p73 belongs to the p53 family of transcription factors, which also includes p63. Compared with the spontaneous tumor development in the $p 53^{-/-}$mice and the epidermal defects in the $p 63^{-/-}$mice (Yang et al. 2002), the effects of $p 73$ loss are more diverse, and a unifying mechanism has long been sought. Now, based on the striking similarities in the phenotypes of $p 73^{-/-}$mice to mice devoid of the master regulator of the motile cilia Foxj1 (Brody et al. 2000), Nemajerova et al. (2016) investigated the possible involvement of p73 in multiciliogenesis. Through a thorough analysis of the airways, they found fewer and shorter motile cilia in $p 73^{-/-}$mice compared with their wildtype counterparts. The subsequent accumulation of exogenous factors in the lungs of $p 73^{-/-}$mice led to macrophage recruitment, chronic bronchitis, and secondary emphysema. Since p73 encodes two sets of isoforms, TAp73 isoforms with an $\mathrm{N}$-terminal transactivation domain and $\Delta \mathrm{Np} 73$ isoforms lacking this domain, the investigators inspected tracheas and bronchi of TAp 73 isoform-specific knockout mice and found that they phenocopied the $p 73^{-/-}$mice, thus implicating TAp73 in

[Keywords: TAp73; p73; TP73; motile multiciliogenesis; central transcriptional regulator; airways]

Corresponding author: elsaflores@mdanderson.org

Article is online at http://www.genesdev.org/cgi/doi/10.1101/gad.283663. 116. multiciliogenesis. These alterations are in line with the spontaneous lung adenocarcinoma predisposition in $p 73^{+/-}$and $p 73^{-1-}$ mice (Flores et al. 2005) and TAp73-/mice (Tomasini et al. 2008). To ascertain the underlying molecular mechanism, Nemajerova et al. (2016) performed RNA sequencing analysis of wild-type and $p 73^{-1-}$ tracheal epithelial cells. These genome-wide data showed that p73 affected the expression of 50 genes required for ciliary formation and motility, eight of which are found mutated in human ciliopathies (Fliegauf et al. 2007). Importantly, this set of genes included key ciliogenic transcription factors whose control by TAp73 was also confirmed in human cells, therefore establishing the evolutionary conservation of this regulation. One of these TAp73 direct target genes, Foxi1, was able to rescue the ciliary defects when overexpressed in $p 73^{-/-}$tracheal epithelial cells, thus indicating that TAp73 is a central regulator of multiciliogenesis acting upstream of Foxi1.

A direct link between p73 and Foxj1 was also recently published by the Pietenpol laboratory (Marshall et al. 2016). They found defects in p73-deficient multiciliated cells in several organs and that p73 could only be detected in $50 \%$ of basal cells of the trachea, where it colocalized with its family member and basal cell marker p63. Interestingly, in $p 73^{-/-}$tracheas, the percentage of basal cells was lower than in wild-type mice, and the ratio among the differentiated cell types was altered, thus implying that loss of $p 73$ profoundly affected basal cell maintenance and differentiation.

Both of these studies greatly advance our comprehension of multiciliogenesis regulated by $\mathrm{p} 73$ and provide a unifying explanation for the variegate phenotypes of the $p 73^{-/-}$mice (Fig. 1). At the same time, these studies raise several questions regarding the interactions of the p53 family members in lung biology. In particular, what are the different biological functions of the $\mathrm{p} 63^{+} / \mathrm{p} 73^{+}$basal cells compared with the p $63^{+}$ones? Furthermore, even though the Moll group (Nemajerova et al. 2016) demonstrated TAp73 requirement in multiciliogenesis, does

(C) 2016 Napoli and Flores This article is distributed exclusively by Cold Spring Harbor Laboratory Press for the first six months after the full-issue publication date (see http://genesdev.cshlp.org/site/misc/terms.xhtml). After six months, it is available under a Creative Commons License (Attribution-NonCommercial 4.0 International), as described at http:// creativecommons.org/licenses/by-nc/4.0/. 


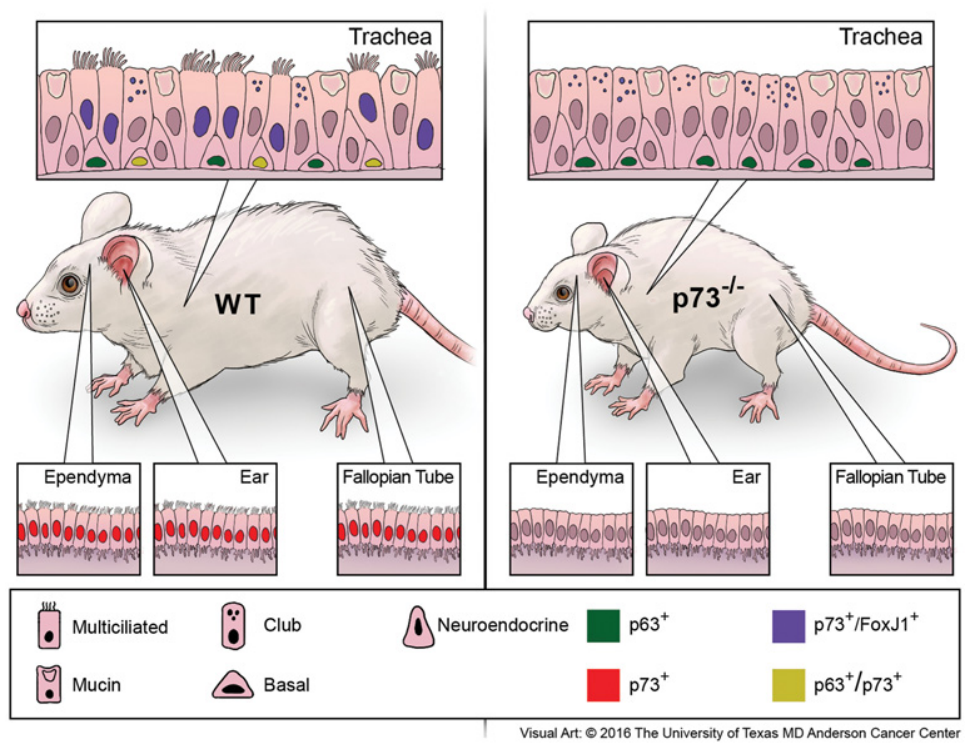

Figure 1. The phenotypes of the $p 73^{-/-}$mice reveal $\mathrm{p} 73$ as a master regulator of multiciliogenesis. Wild-type mice express p73 (red) in multiciliated cells of different organs. In the trachea, p73 is expressed in $50 \%$ of basal cells with p63 (yellow) and in all of the multiciliated cells with Foxi1 (purple). All of the remaining cells are $p 73$ negative (gray nuclei).
$\Delta N p 73$ have a role too? Finally, given that TAp63 and TAp73 can also have overlapping functions (Napoli and Flores 2013) and that both p63 and p73 regulate cilia-associated genes (Marshall et al. 2016), is TAp63 involved in multiciliogenesis? Addressing these questions will be essential to elucidate the isoform-specific roles and the interplay of the p53 family members in lung physiology and diseases.

\section{Acknowledgments}

We thank J.T. Pietz for art production. E.R.F. is a National Cancer Institute Outstanding Investigator (R35CA197452) and scholar of the Leukemia and Lymphoma Society, the Rita Allen Foundation, and the V Foundation for Cancer Research. M.N. is a Cancer Prevention and Research Institute of Texas (CPRIT)-TRIUMPH Scholar (RP140106).

\section{References}

Brody SL, Yan XH, Wuerffel MK, Song SK, Shapiro SD. 2000. Ciliogenesis and left-right axis defects in forkhead factor HFH-4-null mice. Am J Respir Cell Mol Biol 23: 45-51.
Fliegauf M, Benzing T, Omran H. 2007. When cilia go bad: cilia defects and ciliopathies. Nat Rev Mol Cell Biol 8: 880-893.

Flores ER, Sengupta S, Miller JB, Newman JJ, Bronson R, Crowley D, Yang A, McKeon F, Jacks T. 2005. Tumor predisposition in mice mutant for p63 and p73: evidence for broader tumor suppressor functions for the p53 family. Cancer Cell 7: 363-373.

Marshall CB, Mays DJ, Beeler JS, Rosenbluth JM, Boyd KL, Santos Guasch GL, Shaver TM, Tang LJ, Liu Q, Shyr Y, et al. 2016. p73 is required for multiciliogenesis and regulates the Foxj1associated gene network. Cell Rep 14: 2289-2300.

Napoli M, Flores ER. 2013. The family that eats together stays together: new p53 family transcriptional targets in autophagy. Genes Dev 27: 971-974.

Nemajerova A, Kramer D, Siller SS, Herr C, Shomroni O, Pena T, Suazo CG, Glaser K, Wildung M, Steffen H, et al. 2016. TAp73 is a central transcriptional regulator of airway multiciliogenesis. Genes Dev (this issue). doi: 10.1101/gad.279836.116.

Tomasini R, Tsuchihara K, Wilhelm M, Fujitani M, Rufini A, Cheung CC, Khan F, Itie-Youten A, Wakeham A, Tsao MS, et al. 2008. TAp73 knockout shows genomic instability with infertility and tumor suppressor functions. Genes Dev 22: 2677-2691.

Yang A, Kaghad M, Caput D, McKeon F. 2002. On the shoulders of giants: p63, p73 and the rise of p53. Trends Genet 18: 90-95. 


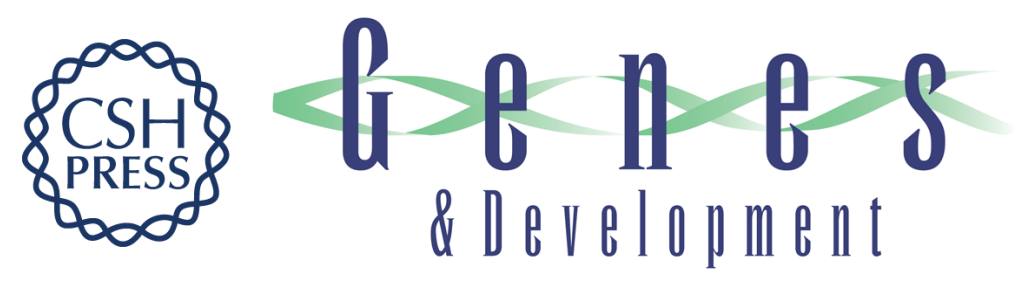

\section{Unifying the p73 knockout phenotypes: TAp73 orchestrates multiciliogenesis}

Marco Napoli and Elsa R. Flores

Genes Dev. 2016, 30:

Access the most recent version at doi:10.1101/gad.283663.116

Related Content TAp73 is a central transcriptional regulator of airway multiciliogenesis

Alice Nemajerova, Daniela Kramer, Saul S. Siller, et al.

Genes Dev. June, 2016 30: 1300-1312

References This article cites 8 articles, 3 of which can be accessed free at:

http://genesdev.cshlp.org/content/30/11/1253.full.html\#ref-list-1

Articles cited in:

http://genesdev.cshlp.org/content/30/11/1253.full.html\#related-urls

Creative This article is distributed exclusively by Cold Spring Harbor Laboratory Press for the first Commons six months after the full-issue publication date (see

License http://genesdev.cshlp.org/site/misc/terms.xhtml). After six months, it is available under a Creative Commons License (Attribution-NonCommercial 4.0 International), as described at http://creativecommons.org/licenses/by-nc/4.0/.

Email Alerting Receive free email alerts when new articles cite this article - sign up in the box at the top Service right corner of the article or click here.

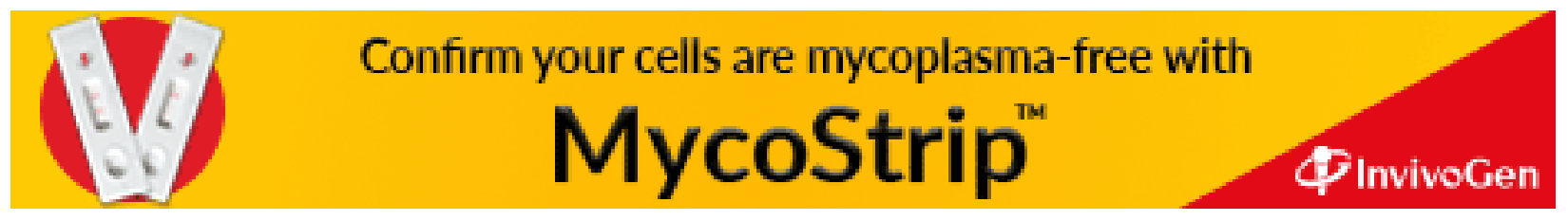

